Historic, Archive Document

Do not assume content reflects current scientific knowledge, policies, or practices. 



\section{Specials in Evergireens}

Japanese Iris, all colors, per hundred ………………….......\$ $\$ 5.00$

Red Snowberries, 12 to 15 inch, per hundred .......................\$ 7.50

Hall's Honeysuckle, (Evergreens), good stocks and

roots, per hundred

$\$ 7.50$

Red Cedars, once transplanted, 12 to 15 inches

high, per hundred

Platt River Seedling Cedars, 4 tr 6 inches high

pe! hundred .......................................................\$ 2.00

Engleman Spruce, 8 to 10 inches high once

transplanted, per hundred

$\$ 15.00$

Hovie's Golden Arborvita, once transplanted,

6 to 8 inches high, per hundred

$\$ 25.00$

Hard or Sugar Maple, 4 to 5 feet, each ................................. .50

Black Hill Spruce, 24 to 36 inches, each ............................... $\quad .50$

Cedars, Pines, Arborvitas and Spruce, all Sizes Write For Prices in Large Quantities

\section{THE PAWNEE ROCK NURSERY}

Pawnee Rock, Kansas 
